\title{
Assessing the vulnerability of women to sexually transmitted diseases STDS/ HIV: construction and validation of markers*
}

\author{
AVALIAÇÃO DA VULNERABILIDADE DE MULHERES ÀS DOENÇAS SEXUALMENTE \\ TRANSMISSÍVEIS - DST E AO HIV: CONSTRUÇÃO E VALIDAÇÃ̃O DE MARCADORES
}

\author{
EVALUACIÓN DE LA VULNERABILIDAD DE MUJERES A LAS ENFERMEDADES DE \\ TRANSMISIÓN SEXUAL - ETS/VIH: CONSTRUCCIÓN Y VALIDACIÓN DE MARCADORES
}

\section{Mónica Cecilia De la Torre Ugarte Guanilo', Renata Ferreira Takahashi², Maria Rita Bertolozzi}

\begin{abstract}
Objective: To construct and validate markers of vulnerability of women to STDs/ HIV, taking into consideration the importance of STDs/HIV. Method: Methodological study carried out in three stages: 1) systematic review and identification of elements of vulnerability in the scientific production; 2) selection of elements of vulnerability, and development of markers; 3) establishment of the expert group and validation of the markers (content validity). Results: Five markers were validated: no openness in the relationship to discuss aspects related to prevention of STDs/HIV; no perception of vulnerability to STDs/HIV; disregard of vulnerability to STDs/ HIV; not recognizing herself as the subject of sexual and reproductive rights; actions of health professionals that limit women's access to prevention of STDs/HIV. Each marker contains three to eleven components. Conclusion: The construction of such markers constituted an instrument, presented in another publication, which can contribute to support the identification of vulnerabilities of women in relation to STDs/HIV in the context of primary health care services. The markers constitute an important tool for the operationalization of the concept of vulnerability in primary health care and to promote inter/multidisciplinary and inter/ multi-sectoral work processes.
\end{abstract}

\section{DESCRIPTORS}

Women

Health vulnerability

Sexually transmitted diseases

HIV

Acquired immunodeficiency syndrome

Nursing in public health

\section{RESUMO}

Objetivo: Construir e validar marcadores de vulnerabilidade de mulheres às DST/HIV. Tendo em vista a relevância das DST/HIV. Método: Estudo metodológico desenvolvido em três etapas: 1 ) revisão sistemática e identificação de elementos de vulnerabilidade na produção científica; 2) seleção dos elementos de vulnerabilidade, e elaboração de marcadores; 3 ) constituição de grupo de Especialistas e validação dos Marcadores (Validade de Conteúdo). Resultados: Foram validados cinco marcadores: Não abertura no relacionamento para discutir aspectos relacionados à prevenção das DST/HIV; Não percepção da vulnerabilidade às DST/ HIV; Desconsideração da vulnerabilidade às DST/HIV; Não reconhecimento de si próprio como sujeito de direitos sexuais e reprodutivos; Ações dos profissionais de saúde que limitam o acesso das mulheres à prevenção das DST/HIV. Cada marcador contém três a onze componentes. Conclusão: A construção de tais marcadores configura um instrumento, apresentado em outra publicação, que pode contribuir para apoiar a captação de vulnerabilidades de mulheres em relação às DST/HIV, no âmbito dos serviços da Atenção Primária à Saúde. Os marcadores se constituem em importante ferramenta para operacionalizar o conceito de vulnerabilidade na Atenção Básica à Saúde e promover processos de trabalho inter/multidisciplinares e inter/multisetoriais.

\section{DESCRITORES \\ Mulheres \\ Vulnerabilidade em saúde \\ Doenças sexualmente transmissíveis HIV \\ Síndrome da imunodeficiência adquirida Enfermagem em saúde pública}

\section{RESUMEN}

Objetivo: Construir y validar marcadores de vulnerabilidad de mujeres a las ETS/VIH. Método: Estudio de desarrollo metodológico, se realizaron tres etapas: 1) revisión sistemática e identificación de elementos de vulnerabilidad; 2) selección de los elementos de vulnerabilidad y elaboración de; 3 ) constitución de grupo de Especialistas y validación de Marcadores (Validación de Contenido). Resultados: Se validó cinco marcadores: No abertura en la relación para discutir aspectos relacionados a prevenir las ETS/VIH; No percepción de la vulnerabilidad a las ETS/VIH; Desconsideración de la vulnerabilidad a las ETS/VIH; No reconocerse como sujeto de derechos sexuales y reproductivos; Acciones de los profesionales de salud que limitan el acceso a la prevención. Cada marcador estuvo conformado por tres a once componentes. Conclusión: La construcción de tales marcadores constituye un instrumento, presentado en otro artículo, el cual puede ayudar a apoyar la captura de vulnerabilidades de las mujeres en relación a las ETS/VIH en el contexto de los servicios de Atención Primaria de Salud. Los marcadores constituyen importante herramienta para operacionalizar el concepto de vulnerabilidad en la Atención Primaria. Además, promueven procesos de trabajo inter e multidisciplinar e inter e multisectorial. La propuesta de un instrumento basado en dichos marcadores puede apoyar la captura de la vulnerabilidad de las mujeres en relación a las ETS/VIH.

\section{DESCRIPTORES \\ Mujeres \\ Vulnerabilidad en salud \\ Enfermedades de transmisión sexual $\mathrm{VIH}$ \\ Síndrome de inmunodeficiencia adquirida Enfermería en salud pública}

\footnotetext{
*Extracted from the thesis "Construção e validação de marcadores de vulnerabilidade de mulheres às DST/HIV na atenção básica à saúde," School of Nursing, University of São Paulo, 2012. ${ }^{1}$ Ph.D. in Sciences from the School of Nursing, University of São Paulo, São Paulo - São Paulo, Brazil. ${ }^{2}$ Associate Professor of the Department of Nursing in Community Health, School of Nursing, University of São Paulo, São Paulo - São Paulo, Brazil.
} 


\section{INTRODUCTION}

In Brazil, interpretations regarding the transmission of the human immunodeficiency virus (HIV) and the most affected social groups were modified because of evidence that the epidemic indiscriminately impacts any social group, with greater involvement when individual, social or programmatic vulnerabilities overlap. The feminization of the disease, defined as the increasing proportion of new AIDS cases reported in this segment ${ }^{(1)}$, is evidence that has been increasingly found in the epidemiological profile and is a product of the overlap of such dimensions, in addition to other processes related to sexuality and gender perspective, that while still being fundamentally important, will not be addressed in general. Feminization is observed in the evolution of the male/ female ratio (M/F ratio) of new cases of AIDS in the country, which rose from 39 in 1983 to 1.7 in $2013^{(2)}$.

In order to strengthen actions to prevent sexually transmitted diseases (STDs) and HIV, since 2002, the Guidelines for the Prevention of STDs/AIDS, targeting women and, subsequently, the Integrated Plan to Combat the Feminization of AIDS and other STDs, established that analysis and mitigation of the HIV/AIDS epidemic in the female population, must be considered from the concept of vulnerability ${ }^{(1,3-5)}$. However, limitations to interventions are still identified, such as the prevalence of the notion of risk and behavior groups, which leads to interventions aimed at changing people's behavior, through the transfer of information characterized as prescriptive, authoritarian, directive and punctual ${ }^{(4,6-9)}$.

This situation has prompted the need to draw on elements that, in the present study, are termed markers, which can support the identification of vulnerabilities, in order to guide intervention actions. Indicators available in Brazil, within the scope of STDs/ HIV, such as the MONITORAIDS ${ }^{(10)}$ and the São Paulo Panel of Aids Indicators (Painel Paulista de Indicadores de Aids) ${ }^{(11)}$, despite their importance, have limited sensitivity for identifying vulnerability contexts, as they do not integrate important issues such as: the capacity of women to make decisions related to their sexual health; the effective possibilities of accessing, carrying or negotiating the use of condoms; the skills to address issues involving STDs with the partner, among others.

In order to contribute to the identification of such contexts of vulnerability, this article aims to present the process of construction and validation of markers of vulnerability of Brazilian women to STDs/HIV. It is considered that such markers have potential application in the context of primary health care units, the primary space where teams that comprise primary health care $(\mathrm{PHC})$ perform their activities.

\section{METHOD}

In this study of methodological development ${ }^{(12)}$, markers of vulnerability of women to STDs/HIV were constructed and validated. The concept of vulnerability proposed by Ayres et al. (2006) ${ }^{(6)}$, which departed from that which was proposed by Mann and Tarantola ${ }^{(13)}$, constituted the theoretical framework. These authors attribute HIV infection and AIDS to the social aspects, to the political commitment of governments and of social institutions, in addition to aspects relating to people.

The construction of the markers of vulnerability of women to STDs/HIV consisted of three stages.

First step: A systematic review and identification of elements of vulnerability. This step included expansion of the systematic review performed in a previous study of the period from 1996 to $2007^{(14)}$, to include 2008 to 2012. To this end, the same data sources were used: CINAHL, PubMed, OVID, Web of Science, LILACS, Digital Library of Theses, Dissertations from CAPES (Biblioteca Digital de Teses e Dissertações da CAPES) and Bibliographical Database of the University of São Paulo. The guiding question was: What are the elements considered in the characterization and analysis of vulnerability of Brazilian women to HIV?

Qualitative studies included: a) published in English, Portuguese or Spanish; b) on adults (18-44 years), male and/or female, with results presented separately (male and female) on vulnerability of women to be seropositive or seronegative for HIV, of any race, ethnicity or social class, heterosexual, not deprived of their liberty, non-users of drugs and no sex workers; c) coming from doctoral theses, master's degree dissertations and articles. Each study was assessed by two researchers independently, considering methodological rigor, credibility and relevance. To this end, we used an adaptation of the instrument provided by the Critical Appraisal Skills Programme (CASP) for qualitative studies. This instrument consists of nine items, allowing classification of studies as good quality, with less risk of methodological bias (satisfactory for six to nine items, which constituted Group A) or regular quality, with greater risk of bias (satisfactory for five or fewer items, which constituted Group B) $)^{(15)}$.

The data were recorded in a summary sheet, consisting of: publication type, affiliation of the first author, geographical location of the study, language, objectives, characteristics of the population and results. From these data, the elements of vulnerability, were revised jointly by members of the Research Group on Vulnerabilities, Adherence and Needs in Community Health of the School of Nursing, University of São Paulo were identified, and registered in the Directory of Research Groups of the National Council for Scientific and Technological Development (CNPq) of Brazil, aiming to correct errors in analysis and adjust the names of the terms used for the elements of vulnerability, seeking to ensure the interpretive validity ${ }^{*}$ of this procedure. In addition, we added the elements of vulnerability extracted from the Integrated Plan to Combat the Feminization of AIDS and other STDs in the state of São Paulo.

* Includes recognition of the correspondence between the data recorded by the reviewer, the reviewer's interpretation and the content of the study. 
Second stage: Selection of the elements of vulnerability and development of the markers. After identification of the elements of vulnerability, we proceeded to select those with the potential to be operationalized within PHC, in order to facilitate capture of the vulnerabilities of women by healthcare professionals in the day-to-day routine of providing health care. The selected elements of vulnerability were grouped according to their similarity, assigning the term marker to the central element of the theme extracted and components of the marker to the elements that constituted it. We conducted an initial evaluation of the components of the markers following the criteria below: 1) subject to prospective measurement; 2) relevance to the objectification of women's vulnerability to STDs/HIV; and 3) likely to be used by healthcare professionals in $\mathrm{PHC}^{(16)}$. For each marker, we elaborated tools to enable its construction: operational manual (OM), assessment spreadsheet (AS) and an instrument for the recording of the judgments of the experts regarding content validation of the markers.

Third stage: Formation of the group of experts and validation of the markers. The number of experts recommended by the literature, to constitute a group, ranges from two to ten ${ }^{(17)}$ and from eight to $140^{(18)}$. There are authors who consider that this number depends on the phenomenon being studied and the criteria for selecting experts $^{(19)}$, as well as the experience and skills of the specialists to analyse the proposed theme ${ }^{(20)}$. In this study, the selection of experts was determined by the degree of knowledge about: the concept of vulnerability, the field of health promotion, construction of indicators and experience in assessing practices for preventing STDs/HIV.

We used the content validation technique and, for this purpose, the experts delivered judgment on the markers. This procedure was carried out in three phases. 1st Stage: Sending to the experts, by regular mail, the OM, the AS of the markers and the instrument for the recording of the judgment. 2nd Stage: Workshop with the experts and members of the Research Group on Vulnerability, Adherence and Needs in Community Health, in order to discuss the changes suggested by the experts, in relation to the $\mathrm{OM}$ and the AS. With the prior permission of the experts, the discussion was recorded. 3rd Phase: The specialists received, by mail, the $\mathrm{OM}$ and the $\mathrm{AS}$, along with the instrument containing the record of the new judgment.

Thus, the experts proceeded in the following manner:

a) In relation to the operational manual: they replied by agreeing or disagreeing (Yes or No) with these questions: 1) Is the purpose of the marker clear, in terms of understanding what the indicator measures and its importance in the prevention of STDs/HIV in the female population?; 2) Do the sources of information enable the application of the marker, are they sufficient, accessible and free of charge? 3) Are the criteria for assessing the data obtained on the component clear and do not allow for different interpretations? b) In respect to all of the components of each marker as a whole: They evaluated their attributes in order to identify whether they were attributable (i.e., if they reflect vulnerability to STDs / HIV), affordable (information may be accessed without charge), communicable (the significance of this measure can be understood), precise (measure what they intend to measure) and achievable (the measures can be applied). For the judgment we used the psychometric scale: does not include the attribute (1); includes the attribute, but needs to be revised (2), and includes the attribute (3).

c) In relation to the attributes of each component of the marker: They evaluated the attributes: simplicity (expresses a single idea), clarity (uses phrases with simple expressions), precision (each component is distinct from other components of the marker).

c) Regarding the assessment of the relevance of each marker: They defined whether each component of the marker was relevant in assessing vulnerability of Brazilian women to STDs/HIV, based on the following psychometric scale: (1) not relevant, (2) somewhat relevant, (3) relevant and (4) very relevant. Additionally, they registered suggestions when the component was not very relevant.

It was considered that there was agreement when obtaining $60 \%$ of positive judgments for the scores 2 and/or 3 for the scales of 1 to 3 and 3 and/or 4 for the scales of 1 to 4 . When we obtained agreement levels below $60 \%$, we considered the observations made by the experts for adjustment. The adopted level of agreement is supported by the literature, being that levels ranging from $50 \%$ to $90 \%^{(20-22)}$ are recommended. Brazilian studies define a minimum agreement level of $75 \%{ }^{(23-24)}$, while there are authors who claim that the level of agreement is arbitrary and proposed by researchers ${ }^{(18)}$.

The research project was approved by the Research Ethics Committee of the School of Nursing of the University of São Paulo (Protocol no. 1020/2011/CEP-EEUSP) and by the Mid-West Regional Health Coordinator of the Municipal Health Department of São Paulo (Official Opinion No. 028/12-CEP/SMS, CAAE: 026.0.196.000-11). All participants were informed about the objectives and purpose of the research, as well as the voluntary nature of their participation, in accordance with Resolution No. 196 of October 10, 1996, of the National Health Council. After being made aware, they signed the Free and Informed Consent Form.

\section{RESULTS}

In the first stage of the study, as shown in Figure 1, of the 920 studies identified in both the systematic reviews, 16 studies were selected, being comprised of six articles, eight dissertations and two theses; most were carried out by nurses (six) and psychologists (five). All were classified as being in Group A, according to the CASP. The studies bring to light
Assessing the vulnerability of women to sexually transmitted diseases STDS/ HIV: construction and validation of markers Guanilo MCTU, Takahashi RF, Bertolozzi MR 
elements of women's vulnerability to HIV in the individual, social and programmatic dimensions, from the perspective of 137 Brazilian women, four STD coordinators, 63 nurses and 50 physicians. Studies analyzing vulnerability from the perspective of women represented $75 \%$ (12 studies), six of which were developed with those seropositive for HIV.

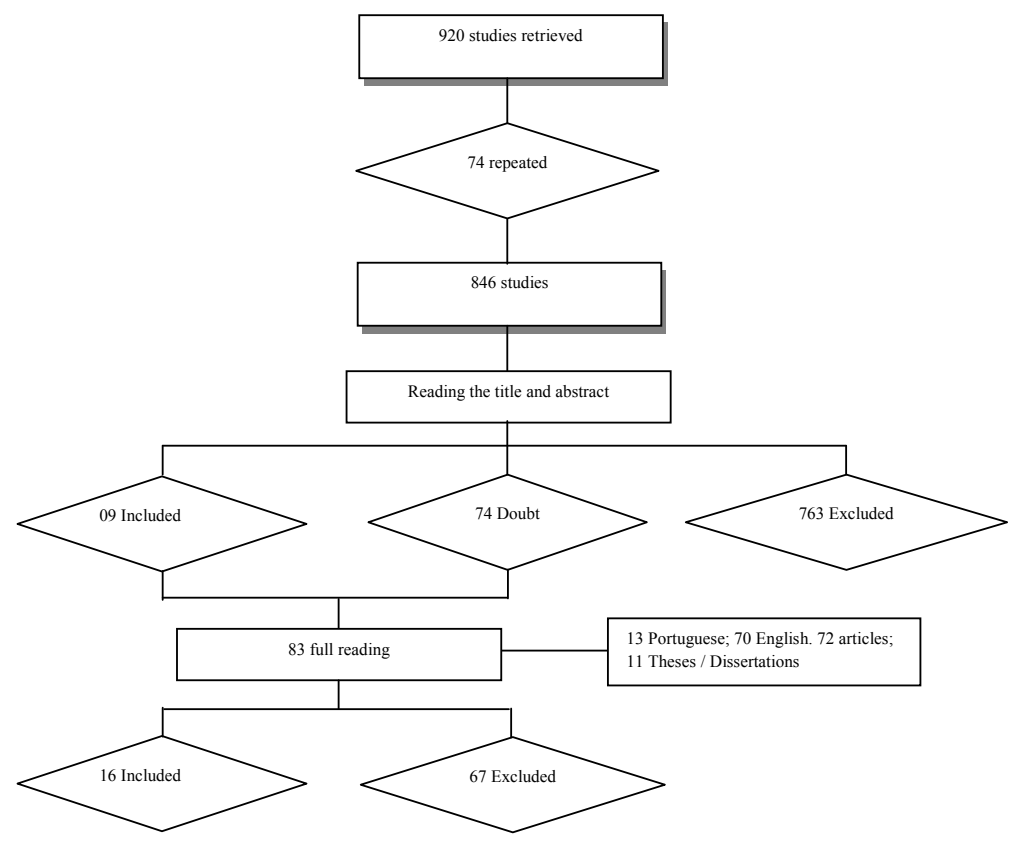

Figure 1 - Process of inclusion and exclusion of studies, following the reading of the title, abstract or full reading - São Paulo, 2011.

The studies were grouped considering the year of publication, when the year in which the research was conducted was not identified, given the interest in relating elements of vulnerability to temporal characteristics of the epidemic. When the study was conducted over a period of time, the starting year of the research was considered. Thus, the three groups that comprised the studies were: 1996-2000, 2001-2005 and 20062011 , the latter concentrated $50 \%$, with a higher proportion of studies conducted in the State of Rio de Janeiro (3), followed by Piauí (2), São Paulo and Paraná, with one study each (Chart 1).

Chart 1 - Studies included in the construction of the markers of vulnerability of Brazilian women to STD/HIV, by period of development of the research or publication - Sao Paulo 2011.

\begin{tabular}{|l|l|l|}
\hline \multicolumn{1}{|c|}{ Studies } & \multicolumn{2}{c|}{ Period } \\
\cline { 2 - 3 } & & $\mathbf{3}$ \\
\hline $\begin{array}{l}\text { 1. Alves RN, Kovacs MJ, Stall R, Paiva V. Psychosocial factors and HIV infection in women (Fatores psicossociais e a infecção por HIV } \\
\text { em mulheres), Maringa, PR. Rev Saúde Pública. 2002;36(4 Supl):32-9. }\end{array}$ & x & \\
\hline $\begin{array}{l}\text { 2. Betini G. Regarding health information for the server as information [dissertation] (Da informação em saúde ao servidor como informa- } \\
\text { ção [dissertação]). São Paulo: School of Public Health, Universidade de São Paulo; 1997. }\end{array}$ & x & \\
\hline $\begin{array}{l}\text { 3. Carvalhaes FF. Subjectivity and AIDS: the experience of illness and militancy in the life trajectory of HIV + women seen from the } \\
\text { perspective of gender studies [dissertation] (Subjetividade e aids: a experiência da doença e da militância na trajetória de vida de mulheres } \\
\text { HIV+ vista sob a perspectiva dos estudos de gênero [dissertação]). Assis: Faculdade de Letras e Ciências de Assis, Universidade Estadual } \\
\text { Paulista Júlio de Mesquita Filho; 2008. }\end{array}$ & x \\
\hline $\begin{array}{l}\text { 4. Souza MCP, Santo ACGE, Motta SKA. Gender, Women's Vulnerability to HIV/Aids and Preventive Actions at a Neighborhood on the } \\
\text { Periphery of Teresina, Piaui, Brazil. 2008. Saúde Soc. 2008;17(2):58-68. }\end{array}$ & x \\
\hline $\begin{array}{l}\text { 5. Geraldes SM. Bemmalmequer: analysis of women's vulnerability to HIV infection in Brazil and Mexico [dissertation] (análise da } \\
\text { vulnerabilidade feminina à contaminação por HIV no Brasil e no México [dissertação]). São Paulo: School of Philosophy, Language Arts, } \\
\text { Sciences and Humanities, Universidade de São Paulo; 1998. }\end{array}$ & $\mathrm{x}$ & \\
\hline $\begin{array}{l}\text { 6. Maliska ICA, Souza MIC, Silva DMG. Sexual practices and the use of condom among women with HIV/Aids. Ciênc Cuidado Saúde. } \\
\text { 2007;6(4):471-8. }\end{array}$ & $\mathrm{x}$ & \\
\hline $\begin{array}{l}\text { 7. Neves FRA. Advice for realization of the anti-HIV serology in pregnant women: the facts and utopias [dissertation] (O aconselhamento } \\
\text { para realização da sorologia a anti-HIV em gestantes: factibilidades e utopias [dissertação]). Ribeirao Preto: School of Nursing of Ribeirão } \\
\text { Preto, Universidade de São Paulo; 2003. }\end{array}$ & $\mathrm{x}$ & \\
\hline
\end{tabular}




\begin{tabular}{|c|c|c|c|}
\hline \multirow{2}{*}{ Studies } & \multicolumn{3}{|c|}{ Period } \\
\hline & 1 & 2 & 3 \\
\hline $\begin{array}{l}\text { 8. Paiva MS. Experiencing pregnancy and experiencing HIV seropositivity [thesis]. São Paulo: School of Nursing, Universidade de São } \\
\text { Paulo; } 2000 .\end{array}$ & $\mathrm{x}$ & & \\
\hline $\begin{array}{l}\text { 9. Paiva V, Pupo LR, Barboza R. The right to prevention and the challenges of reducing vulnerability to HIV in Brazil (O direito à preven- } \\
\text { ção e os desafios da redução da vulnerabilidade ao HIV no Brasil). Rev Saúde Pública. 2006;40 Suppl:109-19. }\end{array}$ & & & $\mathrm{x}$ \\
\hline $\begin{array}{l}\text { 10. Pereira FCQ. Institutional political Program Guidelines on Sexually Transmitted Diseases and AIDS in Marília from the perspective of } \\
\text { the concept of vulnerability [dissertation] (Diretrizes político institucionais do Programa de Doenças Sexualmente Transmissíveis e AIDS } \\
\text { do município de Marília sob a perspectiva do conceito de vulnerabilidade [dissertação]). São Paulo: School of Nursing, Universidade de } \\
\text { São Paulo; } 2009 \text {. }\end{array}$ & & & $\mathrm{x}$ \\
\hline $\begin{array}{l}\text { 11. Bellenzani R. Sexuality among youths of touristic communities: challenges for prevention of STDs / HIV and family health program } \\
\text { [dissertation] (Sexualidade entre jovens das comunidades anfitriãs de turismo: desafios para a prevenção das DST/HIV e o programa saúde } \\
\text { da família [dissertação]). São Paulo: Institute of Psychology, Universidade de São Paulo; } 2008 \text {. }\end{array}$ & & & $\mathrm{x}$ \\
\hline $\begin{array}{l}\text { 12. Saldanha AAW. Vulnerability and constructs of coping with seropositivity to HIV for women infected in stable relationships [thesis] } \\
\text { (Vulnerabilidade e construções de enfrentamento da soropositividade ao HIV por mulheres infectadas em relacionamento estável [tese]). } \\
\text { Ribeirao Preto: School of Philosophy, Language Arts, Sciences and Humanities, Universidade de São Paulo; } 2003 .\end{array}$ & & $\mathrm{X}$ & \\
\hline $\begin{array}{l}\text { 13. Silva CM, Vargens OMC. The perception of women regarding the women's vulnerability to STI / HIV (A percepção de mulheres } \\
\text { quanto à vulnerabilidade feminina para contrair DST/HIV). Rev Esc Enferm USP. 2009;43(2):401-6. }\end{array}$ & & & $\mathrm{x}$ \\
\hline $\begin{array}{l}\text { 14. Silva CM. The perception of women in stable relationships regarding the vulnerability to STDs / AIDS [dissertation] (A percepção de } \\
\text { mulheres, em relacionamento estável, quanto à vulnerabilidade para contrair DST/aids [dissertação]). Rio de Janeiro: School of Nursing, } \\
\text { Universidade do Estado de Rio de Janeiro; } 2008 \text {. }\end{array}$ & & & $\mathrm{X}$ \\
\hline $\begin{array}{l}\text { 15. Sousa JHM, Paiva MS. Vulnerability of young people to HIV infection and the social representations of AIDS (Vulnerabilidade de } \\
\text { jovens frente a infecção pelo HIV e as representações sociais da AIDS). Rev Baiana Enferm. 2002;17(3):55-64 }\end{array}$ & & $\mathrm{x}$ & \\
\hline $\begin{array}{l}\text { 16. Sousa MCP. The gender question in HIV / AIDS prevention actions for women, developed by the team of family health in Teresina - PI } \\
\text { [dissertation] (Questão de gênero nas ações de prevenção do HIV/AIDS em mulheres, desenvolvidas pela equipe de saúde da família no } \\
\text { município de Teresina - PI [dissertação]). Recife: Universidade Federal de Pernambuco; } 2007 \text {. }\end{array}$ & & & $\mathrm{X}$ \\
\hline
\end{tabular}

Legend 1: period 1996-2000; 2: period 2001-2005; 3: period 2006-2011.

In the second stage of the study, we selected the elements of vulnerability that were actionable in PHC, which gave rise to the formation of four markers reflecting how social norms and health management influence vulnerability of women. We elaborated an operational manual for each marker with the items: name of the marker and identification code (M1, M2, M3, M4); importance of the marker; marker type (individual, social or programmatic vulnerability); information sources for the data collection; and evaluation criteria. The assessment spreadsheet of each marker contained the items: name of the marker; components of the marker; criteria for evaluation: present $(P)$, not present (NP) or not applicable (NA) in the social context of women, and observations of the professional applying the instrument.

The group of experts who participated in the third stage of the study consisted of five nurses and a physician. However, in the second phase of validation, one nurse had professional limitations that prevented her from participating. The experts suggested: exclusion of some markers; inclusion of new markers and components; relocation of components into other markers; and improvement of wording in order increase clarity.

Chart 2 presents the final version of the markers of vulnerability after the validation process.

Chart 2 - Markers of vulnerability after the validation process - São Paulo 2011.

\begin{tabular}{|c|c|c|c|c|}
\hline \multirow{2}{*}{ 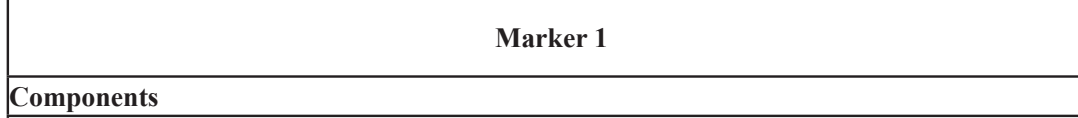 } & \multicolumn{4}{|c|}{$\begin{array}{l}\text { No openness in the relationship to discussing } \\
\text { aspects related to prevention of the STDs/HIV }\end{array}$} \\
\hline & $\mathbf{P}$ & $\mathbf{A}$ & NA & Comments \\
\hline \multicolumn{5}{|l|}{$\begin{array}{l}\text { The woman finds it difficult to initiate a conversation about the transmission and prevention of } \\
\text { STDs / HIV }\end{array}$} \\
\hline \multicolumn{5}{|l|}{ The woman has difficulty in proposing the use of male or female condoms } \\
\hline \multicolumn{5}{|l|}{ The woman expresses a prejudice against women who carry condoms, routinely } \\
\hline Marker 2 & \multicolumn{4}{|c|}{ No perception of vulnerability to STDs/HIV } \\
\hline Components & $\mathbf{P}$ & $\mathbf{A}$ & NA & Comments \\
\hline The woman does not know if her partner is a carrier of STDs/HIV & & & & \\
\hline The woman does not consider condom use, despite having had previous experience with STDs & & & & \\
\hline $\begin{array}{l}\text { The woman does not know or does not have adequate knowledge about transmission and pre- } \\
\text { vention of STDs/HIV }\end{array}$ & & & & \\
\hline The woman associates STDs/HIV to risk groups and protection to stable relationships & & & & \\
\hline
\end{tabular}




\begin{tabular}{|c|c|c|c|c|}
\hline Marker 2 & \multicolumn{4}{|c|}{ No perception of vulnerability to STDs/HIV } \\
\hline Components & $\mathbf{P}$ & $\mathbf{A}$ & NA & Comments \\
\hline \multicolumn{5}{|l|}{ The woman does not feel vulnerable to STDs/HIV } \\
\hline \multicolumn{5}{|l|}{ The woman does not have access to male or female condoms, and still has intercourse } \\
\hline \multicolumn{5}{|l|}{$\begin{array}{l}\text { Ignorance or uncertainty about services that offer advice for the prevention of STDs/HIV, for } \\
\text { conducting HIV testing in the PHC or in regards to referrals by the PHC to the Counseling and } \\
\text { Testing Center (Centro de Testagem e Aconselhamento)-CTA) }\end{array}$} \\
\hline \multicolumn{5}{|l|}{ The woman knows that the partner has multiple partners } \\
\hline \multicolumn{5}{|l|}{ The woman knows that the partner is HIV positive } \\
\hline Marker 3 & \multicolumn{4}{|c|}{ Does not consider herself vulnerable to STDs/HIV } \\
\hline Components & $\mathbf{P}$ & $\mathbf{A}$ & NA & Comments \\
\hline \multicolumn{5}{|l|}{ The partner refuses to use condoms for any reason } \\
\hline \multicolumn{5}{|l|}{ The woman considers it normal for her partner to have multiple partners to be normal } \\
\hline \multicolumn{5}{|l|}{$\begin{array}{l}\text { The disregard of condom use by the women, for wanting to get pregnant, is not the object of } \\
\text { attention by the healthcare service }\end{array}$} \\
\hline \multicolumn{5}{|l|}{$\begin{array}{l}\text { The woman has (has had) unprotected sexual intercourse with an unknown partner: because of } \\
\text { economic dependence on the partner }\end{array}$} \\
\hline Marker 4 & \multicolumn{4}{|c|}{$\begin{array}{l}\text { Not recognizing herself as the subject of sexual } \\
\text { and reproductive rights }\end{array}$} \\
\hline Components & $\mathbf{P}$ & $\mathbf{A}$ & NA & Comments \\
\hline \multicolumn{5}{|l|}{ The woman feels difficulties in expressing her needs for attention and affection to the partner } \\
\hline \multicolumn{5}{|l|}{ The woman does not find satisfaction in the relationship with the partner } \\
\hline \multicolumn{5}{|l|}{\begin{tabular}{|l} 
The responsibility for sexual and reproductive health is up to the woman \\
\end{tabular}} \\
\hline Marker 5 & \multicolumn{4}{|c|}{$\begin{array}{l}\text { Actions of healthcare professionals that limit } \\
\text { women's access to prevention of STDs/HIV }\end{array}$} \\
\hline Components & $\mathbf{P}$ & $\mathbf{A}$ & NA & Comments \\
\hline \multicolumn{5}{|l|}{$\begin{array}{l}\text { Preventive actions aimed at the population in general are performed sporadically (on certain } \\
\text { occasions such as: Carnival, International Day of AIDS) without being sustained by the } \\
\text { healthcare provider }\end{array}$} \\
\hline \multicolumn{5}{|l|}{ The health service is not open to the public daily } \\
\hline \multicolumn{5}{|l|}{ Actions to prevent STDs/HIV are not embedded transversely in health practices } \\
\hline \multicolumn{5}{|l|}{ The pre- and post-HIV test counseling is not performed by health professionals } \\
\hline \multicolumn{5}{|l|}{ The male population is excluded from preventive actions } \\
\hline \multicolumn{5}{|l|}{ Preventive actions are not evaluated } \\
\hline \multicolumn{5}{|l|}{ Preventive actions are more geared towards women of certain groups } \\
\hline \multicolumn{5}{|l|}{$\begin{array}{l}\text { Health professionals are unaware of the epidemiology of STDs/HIV of their service territory, } \\
\text { limiting the planning of prevention }\end{array}$} \\
\hline \multicolumn{5}{|l|}{$\begin{array}{l}\text { Health professionals are unaware of the local contexts of women's vulnerability to STDs/HIV, } \\
\text { such as physical and psychological aggression, and other STDs/HIV }\end{array}$} \\
\hline \multicolumn{5}{|l|}{ Limited communication in management councils on the vulnerabilities of women to STDs/HIV } \\
\hline Preventive actions are neither multi/inter-sectoral nor multi/interdisciplinary & & & & \\
\hline
\end{tabular}

Legend: P: Present; A: absent; NA: Not applicable

\section{DISCUSSION}

This study aimed to construct and validate markers of vulnerability of Brazilian women to STDs/HIV within primary health care. To ensure content validity in construction of the markers, i.e., to ensure that they adequately represent the concept/content to be measured, in this case women's vulnerability to STIS/HIV, it is recommended that the coverage area be continually reviewed, in order to ensure that key issues are adequately addressed ${ }^{(25)}$. In this sense, the systematic review, in order to subsidize the construction of the markers, was considered to be a strengthening factor for ensuring the validity of their content.

The fact that all studies are in Group A, according to the CASP, may reflect the demands that must be met for editors of journals to accept articles, and also the fact that dissertations and doctoral theses have been included, which provide detailed information on the methodology and results of the research developed.

The increasing proportion of studies has accompanied the development of the epidemic in the female population and the proposed actions for coping. Regarding the development of the epidemic, Brazilian data show a progressive increase in the detection rate of AIDS in women. In the first period, from 1996 to 2000, the rate increased from $8.4 / 100,000$ inhabitants to $12.0 / 100,000$. In the second period, from 2001 to 2005, the rate increased from 12.6/100,000 to $15.3 / 100,000$. And in the last period, from 2006 to 2011 , the rate increased from $14.7 / 100,000$ to $15.2 / 100.000^{(2)}$. The latter period coincides with the implementation in 2007 
of the Comprehensive Plan to Combat the Feminization of AIDS and other STDs, embodying the institutionalization of the use of the concept of vulnerability as a guiding tool for analysis and planning of prevention in the female Brazilian population ${ }^{(4)}$. The progression of the epidemic in this group may have motivated researchers to uncover more aspects of women's vulnerability to HIV.

Most of the studies were developed by nurses and psychologists, which may indicate greater involvement of these professionals in research on the theme, but also indicates the need to involve professionals from other areas in order to increase knowledge of elements of vulnerability and enhance prevention efforts, being that a multidisciplinary approach is considered to be an important strategy for overcoming actions focused on clinical reasoning. It is noteworthy that a systematic review developed with studies on women's vulnerability to STDs/HIV from several countries identified the involvement of professionals from the fields of sociology, economics, anthropology, politics and economics in health ${ }^{(14)}$.

The inclusion of both studies conducted with women living with HIV, as well as those with women who are seronegative, was a strategy that strengthened the construction of the markers of vulnerability, because the elements of vulnerability have been recognized as determinants of increased vulnerability of seronegative women to HIV and infection, in the case of HIV-seropositive women.

The presentation of the markers aims to sensitize and involve health professionals in $\mathrm{PHC}$ in planning of preventive activities, not limited just to the transfer of information, but also to provide spaces for exchange to encourage discussions about knowledge, beliefs and values. Also, this study intended to bring to light the need to incorporate preventive actions of inter/multidisciplinary and inter/multi-sector character, since the way women live out their sexuality is related to their modes of living which, in turn, relate to the social context in which they are inserted. The inter/multidisciplinary and inter/ multi-sectoral character of actions and spaces for exchange with the women may facilitate the identification of convenient means for construction the responses to vulnerability ${ }^{(6)}$.

It is known that both healthcare professionals and the general population have difficulties in addressing issues related to sexual health, as it is a topic marked by prejudices and taboos ${ }^{(9.26)}$. Accordingly, markers of vulnerability can be regarded as important soft technologies, as they enable collecting information, providing opportunities to exchange ideas and planning to overcome vulnerabilities.

\section{REFERENCES}

1. Boletim Epidemiológico DST/Aids. Ministério da Saúde, Brasília. 2013;2(1).

2. Souto CPK, organizadora. Políticas e Diretrizes de Prevenção das DST/AIDS entre Mulheres. Brasília: Ministério da Saúde, Coordenadoria do Programa Nacional de DST e Aids; 2002.
Content validity, which was used to validate the markers, verifies the respective ability or sufficiency to measure what it is intended, in this case women's vulnerability to STDs/HIV ${ }^{117-}$ ${ }^{18.21)}$. However, this does not exhaust assessment of women's vulnerability to STDs/HIV, because beyond the complexity of vulnerability, the markers need to be tested for their internal and external reliability, when applied empirically. According to the literature, not every instrument that has reliability is valid, but it is considered that any instrument that is valid also shows good reliability ${ }^{(27)}$. It is noteworthy that it is necessary to continue its development, with the objective to translate each component of the markers into specific questions that enable the capture of key information for health interventions.

Finally, it is necessary to emphasize the power of the concept of vulnerability for the interpretation of health disorders, an idea which articulates the dimensions relating to the context in which diseases emerge, to the policies and actions introduced for their control, in addition to the processes that take place from the more singular perspective and which refer to the experience of illness/injury ${ }^{(28)}$.

\section{CONCLUSION}

A systematic review was developed to identify elements of women's vulnerability to STDs/HIV, which allowed for the construction of markers to represent fundamental aspects of vulnerability, which can be approached in a scope of established interest, i.e., primary health care.

The process of content validity allowed for better qualification of the components of the markers of women's vulnerability to STDs/HIV, and ensured that the markers adequately represent the concept of vulnerability.

The validated markers are an important tool for operationalizing the concept of vulnerability in PHC, as it allows for characterization of vulnerability of women, helping to guide planning of preventive actions guided by reality, which are not merely limited to transfer information, but rather include exchange of knowledge, beliefs and values linked to the way women live out their sexuality.

Finally, it is worth noting, as one of the limitations of the study, the fact that systematic reviews capture only one facet of reality. Thus, one must be careful not to extrapolate the data to any other populations, since social groups keep specificity in their formation and history, especially when it comes to a theme involving sexuality and the gender perspective.

3. Brasil. Ministério da Saúde; Secretaria de Vigilância em Saúde. Programa Nacional de DST e AIDS. Plano Integrado de Enfrentamento da Feminização da Epidemia de Aids e outras DST. Brasília; 2007.

4. Salmond SW. Orthopaedic nursing research priorities: a Delphi study. Orthop Nurs. 1994;13(2):31-45.

Assessing the vulnerability of women to sexually transmitted diseases STDS/ HIV: construction and validation of markers Guanilo MCTU, Takahashi RF, Bertolozzi MR 
5. Brasil. Ministério da Saúde; Secretaria Especial de Políticas para as Mulheres da Presidência da República. Plano Integrado de enfrentamento da Feminização da Epidemia de Aids e outras DST: versão revisada. Brasília; 2009.

6. Ayres JRCM, Calazans GJ, Saletti Filho HC, França Júnior I. Risco, vulnerabilidade e práticas de prevenção e promoção da saúde. In: Campos GWS, Minayo MCS, Akerman M, Drumond Júnior M, Carvalho YM, organizadores. Tratado de saúde coletiva. Rio de Janeiro: Hucitec; 2006. p. 354-95.

7. Paiva V, Pupo RL, Barboza R. O direito à prevenção e os desafios da redução da vulnerabilidade ao HIV no Brasil. Rev Saúde Pública. 2006;40 Supl:109-19.

8. Ferraz DAS. Avaliação da implantação de ações de prevenção das DST/Aids numa Unidade de Saúde da Família [dissertação]. São Paulo: Faculdade de Medicina, Universidade de São Paulo; 2009.

9. Cirino FMSB. Ações de prevenção ao HIV/aids na Estratégia Saúde da Família sob a ótica da vulnerabilidade programática [dissertação]. São Paulo: Escola de Enfermagem, Universidade de São Paulo; 2011.

10. Brasil. Ministério da Saúde; Secretaria de Vigilância em Saúde. Programa Nacional de DST/AIDS. Sistema de Monitoramento de Indicadores do Programa Nacional de DST e Aids - MONITORAIDS. Brasília; 2004.

11. São Paulo (estado). Secretaria da Saúde. Painel Paulista de Indicadores deaids [Internet].SãoPaulo;2011 [citado2012mar.14]. Disponível em: http://ppiaids.crt.saude.sp.gov.br/view/index.php

12. PolitDF,HunglerBP.Fundamentos depesquisaemenfermagem. Porto Alegre: Artes Médicas; 1995. Delineamentos de pesquisa; p.107-40.

13. MannJ,TarantolaDJM.AIDSintheworld.NewYork:OxfordUniversity Press; 1996. Vulnerability: personal and programmatic; p.441-62.

14. De-la-Torre-Ugarte-Guanilo MC. Vulnerabilidade feminina ao HIV: metassíntese [dissertação]. São Paulo: Escola de Enfermagem, Universidade de São Paulo; 2008.

15. The University of Kent. Critical Appraisal Skills Programme (CASP). 10 Questions to help you make sense of qualitative research [Internet]. England: Public Health Resource Unit; 2006 [cited 2008 June 25]. Available from: http://www.arf-asia.org/resources/ten_question_to_make_sensible_with_research.pdf

16. Lynn MR. Determination and qualification of content validity. Nurs Res. 1986;35(6): 382-5.
17. Westmoreland D, Wesorick B, Hanson D, Wyngarden K. Consensual validation of clinical model practice guidelines. J Nur Care Qual. 2000;14(4):16-27.

18. Williams PL, Webb C. The Delphi technique: a methodological discussion. J Adv Nurs. 1994;19(1):180-6.

19. PolitDF,BeckCT,HunglerBP.Fundamentosdepesquisaemenfermagem: métodos, avaliação e utilização. Porto Alegre: Artmed; 2004.

20. Pascuali L. Testes referentes a construto: teoria e modelo de construção. In: Pasquali L, organizador. Instrumentos psicológicos: manual práticodeelaboração.Brasília:LabPAM/IBAPP;1999.p.37-71.

21. Polit DF, Beck CT. The content validity index: are you sure you know what's being reported? Critique and recommendations. Res Nurs Health. 2006;29(5):489-97.

22. Fernandes MVL. Indicadores de avaliação de práticas de controle e prevenção de infecção do trato urinário associada a cateter: construção e validação [dissertação]. São Paulo: Escola de Enfermagem, Universidade de São Paulo; 2005.

23. Silva CPR. Indicadores para avaliação de programas de controle de infecção hospitalar: construção e validação [dissertação]. São Paulo: Escola de Enfermagem, Universidade de São Paulo; 2005.

24. Campbell SM, Braspenning J, Hutchinson A, Marshall MN. Improving the quality of health care: research methods used in developing and applying quality indicators in primary care. BMJ. 2003;326(7393):816-9.

25. Sampieri RH, Collado CF, Lucio PB. Metodología de la investigación. México: McGraw Hill; 1996.

26. Brasil. Ministério da Saúde; Secretaria de Atenção à Saúde, Departamento de Atenção Básica. Saúde sexual e saúde reprodutiva. Brasília; 2010. (Cadernos de Atenção Básica, n. 26).

27. Nichiata LYI, Bertolozzi MR, Gryschek ALPL, Araújo NVDAL, Padoveze $\mathrm{MC}$, Ciosak SI, et al. The potential of the concept of vulnerability in understanding transmissible diseases. Rev Esc Enferm USP [Internet]. 2011 [cited 2012 June 14];45(n.spe2):1769-73. Available from: http://www.scielo.br/pdf/reeusp/v45nspe2/en_23.pdf

28. Brasil. Ministério da Saúde; Secretaria Especial de Políticas para as Mulheres da Presidência da República. Plano Integrado de Enfrentamento da Feminização da Epidemia de Aids e outras DST: versão revisada. Brasília; 2011.

\section{Acknowledgments}

To the researchers at the School of Nursing and School of Medicine, Universidade de São Paulo, and professionals of the Epidemiology Division of the Center of Reference and Training in STDs and AIDS in the state of São Paulo who contributed their expertise to the validation study. 